\title{
Analisis butir soal ulangan semester ganjil mata pelajaran matematika kelas VIII SMP pada tahun ajaran 2018/2019
}

\author{
Khairil Basri' ${ }^{1}$, Baidowi², Junaidi², Muhammad Turmuzi ${ }^{2}$ \\ ${ }^{1}$ Mahasiswa Pendidikan Matematika, FKIP, Universitas Mataram, Mataram \\ ${ }_{2}^{2}$ Pendidikan Matematika, FKIP, Universitas Mataram, Mataram
}

khairilbasri13@gimail.com

Diterima: 14-12-2021; Direvisi:30-12-2021; Dipublikasi: 30-12-2021

\begin{abstract}
This study aims to know the quality of Grain Analysis of Odd Semester Test Questions Of Mathematics Subjects Grade VIII at State Junior High School In The Academic Year 2018/2019 which is reviewed in terms of Validity, Reliability, Difficulty Level, Differentiating Power, and Effectiveness of Phishing. This is a descriptive research. The result of this research shows that: in terms of Validity, the amount of valid questions up to 14 points of the question (70\%) and invalid question are up to 6 points of question (30\%); in terms of Reliability, including questions that have high reliability is with a coefficient 0.79 ; in terms of Difficulty Level, the number of questions that are include in the difficult categorythere are 2 points (10\%), which belongs to the moderate category there are 17 items (85\%), and include in easy category there is 1 item(5\%); in terms of Differentiating power, the number of problems categorized as very bad as 1 item (5\%), bad category as much as 1 item (5\%), categorized enough as many as 9 points (45\%), good category as much as 6 items (30\%) and very high category 3 items (15\%); reviewed in terms of Effectiveness of phishing, there are 15 points of question ( $75 \%$ ) with excellent outwits, 5 points of question $(25 \%)$ with a good phishing, 0 point problem $(0 \%)$ with a less bad phishing and with a bad phishing 0 point problem (0\%).
\end{abstract}

Keywords :Validity, Reliability, Difficulty Level, Differentiating Power, Effectiveness of Phishing

\begin{abstract}
Abstrak
Penelitian ini bertujuan untuk mengetahui kualitas Analisis Butir Soal Ulangan Semester Ganjil Mata Pelajaran Matematika Kelas VIII SMP Pada Tahun Ajaran 2018/2019 yang ditinjau dari segi Validitas, Reliabilitas, Tingkat Kesukaran, Daya Pembeda, dan Efektivitas Pengecoh. Teknik pengumpulan data dilakukan dengan metode dokumentasi. Hasil penelitian menunjukkan bahwa: ditinjau dari segi Validitas, soal yang valid berjumlah 14 butir soal (70\%) dan soal yang tidak valid berjumlah 6 butir soal (30\%); ditinjau dari segi Reliabilitas, termasuk soal yang memiliki reliabilitas yang tinggi yaitu dengan koefisien sebesar 0,79; ditinjau dari segi Tingkat Kesukaran, jumlah soal yang termasuk dalam kategori sukar ada 2 butir (10\%), yang termasuk kategori sedang ada 17 butir (85\%), dan yang termasuk dalam kategori mudah ada 1 butir (5\%); ditinjau dari segi Daya Pembeda, jumlah soal yang berkategori sangat jelek sebanyak 1 butir (5\%), berkategori jelek sebanyak 1 butir (5\%), berkategori cukup sebanyak 9 butir (45\%), berkategori baik sebanyak 6 butur (30\%) dan berkategori sangat tinggi 3 butir (15\%); ditinjau dari segi Efektivitas Pengecoh, terdapat 15 butir soal (75\%) dengan pengecoh yang sangat baik, 5 butir soal (25\%) dengan pengecoh yang baik, 0 butir soal (0\%) dengan pengecoh yang kurang baik dan dengan pengecoh tidak baik 0 butir soal (0\%).
\end{abstract}

Kata kunci: Validitas, Reliabilitas, Tingkat Kesukaran, Daya Pembeda, Efektivitas Pengecoh. 


\section{PENDAHULUAN}

Dalam Undang-undang Nomor 20 Tahun 2003 tentang Sistem Pendidikan Nasional Pasal 1 ayat 1 dinyatakan bahwa tujuan pendidikan nasional adalah untuk mewujudkan siswa yang memiliki kekuatan sepiritual keagamaan, pengenalan diri, kepribadian, kecerdasan, akhlak mulia, serta keterampilan yang diperlukan dirinya, masyarakat, bangsa dan Negara.. Berdasarkan tujuan tersebut, dapat dikataakan bahwa pendidikan merupakan peroses pembelajaran yang di arahkan kepada perkembangan siswa untuk memiliki kekuatan spiritual keagamaan, pengendalin diri, kepribadian, kecerdasan, akhlak mulia, serata keterampilan yang diperlukan dirinya, masyarakat bangsa dan dirinya (Jufri, 2013). Untuk mewujudkan hal tersebut, maka pemerintah mendirikan lembaga-lembaga pendidikan mulai dari pendidikan dasar sampai perguruan tinggi. Hal itu dapat dilihat dari banyaknya sekolah-sekolah yang ada hingga saat ini.

Ketika seorang guru memberikan tes atau evaluasi kepada peserta didik diperlukan analisis butir soal untuk mengetahui kualitas butir soal tersebut (Nitko, 1996). mengatakan bahwa : kegiatan menganalisis butir soal merupakan suatu kegiatan yang harus dilakukan untuk meningkatkan mutu soal yang telah ditulis. Kegiatan ini merupakan proses pengumpulan, peringkasan, dan penggunaan informasi dari jawaban peserta didik untuk membuat keputusan peserta didik tentang setiap penilaian. Kegiatan menganalisis merupakan kegiatan yang sangat penting yang harusnya dilakukan oleh semua guru. Hal ini karena melalui kegiatan analisis kita dapat mengetahui dimana letak kesalahan butir soal yang sudah kita buat dan bagaimanakah kualitas dan reliabilitas soal tersebut.

SMP Negeri 1 Kedidri merupakan salah satu SMP Negeri di Kabupaten Lombok Barat. Berdasarkan hasil wawancara dengan guru yang di lakukan hari Rabu, 20 Febuari 2019 di SMP masih banyak peserta didik yang mengalami kesulitan dalam menyelasikan soal ulangan semester ganjil mata pelajaran matematika. Sekolah SMP juga memberikan ruang setiap guru mata pelajaran untuk membuat sendiri soal-soal tes ulangan semester. Sedangkan menurut Hamzah (Hamzah, 2014). menjelaskan: "tes mempunyai perosedur evaluasi yang komperhensif, sistematis, dan objektif yang hasinya dapat di jadikan dasar dalam pengambilan keputusan dalam peroses pengajaran yang di lakukan oleh." Dalam membuat tes banyak guru hanya mengambil dari buku ajar atau buku paket dan internet padahal soal tersebut belum tentu baik untuk dijadikan alat ukur. Selain itu guru juga jarang melakukan analisis butir soal untuk mengetahui kualitas soal.

Hal itu juga dialami oleh guru-guru di SMP. Menurut hasil wawancara dengan guru mata pelajaran matematika, guru tidak pernah melakukan analisis butir soal. Penyebab guru tidak melakukan analisis butir soal yaitu proses kegiatan analisis yang dirasa cukup sulit dan membutuhkan waktu yang lama dalam proses penganalisisan. Selain itu dalam proses menyusun soal guru cenderung mengambil soal dibuku-buku, internet dan berdasarkan periode sebelumnya. Sementara itu, soal-soal yang di ambil belum diketahui kualitas butir soalnya baik dari segi validitas, reliabilitas, tingkat kesukaran, daya beda dan efektivitas pengecoh. Analisis butir soal sangat penting dilakukan untuk memperbaiki kualitas soal dan peningkatan mutu dari soal-soal yang akan diujikan selanjutnya. Kegiatan analisis butir soal ini dapat membantu para guru di SMP untuk mengetahui kualitas butir soal yang diberikan. Analisis butir soal sangat penting untuk mengetahui soal yang baik dan yang kurang baik. Berdasarkan uraian masalah yang ada di SMP, akan di lakukan penelitian dengan judul "Analisis Butir Soal 
Ulangan Semester Ganjil Mata Pelajaran Matematika Kelas VIII SMP Pada Tahun Ajaran 2018/2019".

\section{METODE}

Jenis penelitian ini adalah penelitian deskriptif kuantitatif. Artinya penelitian ini dilakukan secara kuantitatif tetapi tidak untuk menerima atau menolak hipotesis, melainkan untuk menjelaskan keadaan yang apa adanya sesuai dengan keadaan objek yang diteliti. Penelitian ini di lakukan pada kelas VIII. Populasi dalam penelitian ini adalah siswa kelas VIII SMP yang berjumlah 46 Orang. Adapun sampel penelitian ini di lakukan di kelas VIII A dan VIII E SMP.

Teknik analisis data pada butir-butir Soal Ulangan Semester Ganjil Mata Pelajaran Mata Pelajaran Matematika Kelas VIII SMP Pada Tahun Ajaran 2018/2019 dengan mencari validiatas, reliabillitas, tingkat kesukaran, daya pembeda dan efektivitas pengecoh. Masing - masing akan dihitung dengan program microsoft excel. Adapun kriterianya sebagai berikut:

\section{Validitas}

Menurut (Arikunto, 2013) Untuk menghitung Validitas item pada soal pilihan ganda dapat menggunakan rumus seperti:

$$
r_{p b i}=\frac{M_{p}-M_{t}}{S D_{t}} \sqrt{\frac{p}{q}}
$$

$r_{p b i}=$ koefisien korelasi biserial

$M_{p}=$ rerata skor dari subjek yang menjawab betul bagi item yang dicari validitasnya.

$M_{t}=$ rerata skor total

$S D_{t}=$ standar deviasi dari skor total proporsi

$$
p=\frac{\text { banyaknya siswa yang menjawab benar }}{\text { jumlah seluruh siswa }}
$$

$p=$ proporsi siswa yang menjawab benar

$q=$ proporsi siswa yang menjawab salah $(\mathrm{q}=1-\mathrm{p})$

Hasil dari perhitungan koefisien korelasi biserial kemudian dibandingkan dengan pada taraf signifikan 5\% dan disesuaikan dengan jumlah peserta tes. Apabila $y_{p b i}>\mathrm{r}$ tabel maka soal tersebut valid.

\section{Reliabilitas}

Menurut (Arikunto, 2013). Untuk mencari reliabilitas pada soal pilihan ganda dapat digunakan rumus sebagai berikut :

$$
r_{11}=\left(\frac{n}{n-1}\right)\left(\frac{S^{2}-\sum p q}{S^{2}}\right)
$$

Keterangan : 
$r_{11}=$ reliabilitas tes secara keseluruhan

$p=$ proporsi subjek yang menjawab item dengan benar

$\sum p q=$ jumlah perkalian antara $\mathrm{p}$ dan $\mathrm{q}$

$q=$ proporsi subjek yang menjawab item dengan salah

$n=$ jumlah item

$\mathrm{S}=$ standar deviasi dari tes (Akar Varians)

Kriteria untuk menentukan tinggi rendahnya reliabilitas sebuah perangkat tes, menurut Guilford dalam (Sundayana, 2014). yaitu:

Tabel 3.2 Klasifikasi Koefisien Reliabilitas

\begin{tabular}{lc}
\hline \multicolumn{1}{c}{ Interpretasi } & $\begin{array}{c}\text { Koefisien Reliabilitas } \\
(\mathrm{r})\end{array}$ \\
\hline Sangat rendah & $0,00 \leq r<0,20$ \\
Rendah & $0,20 \leq r<0,40$ \\
Sedang / cukup & $0,40 \leq r<0,60$ \\
Tinggi & $0,60 \leq r<0,80$ \\
Sangat Tinggi & $0,80 \leq r<1,00$ \\
\hline
\end{tabular}

3. Tingkat kesukaran

Menurut (Sundayana, 2014). Tingkat kesukaran dapat dihitung dengan rumus sebagai berikut :

Keterangan :

$\mathrm{P}=$ Indeks kesukaran

$$
P=\frac{B}{J S}
$$

$\mathrm{B}=$ Banyaknya siswa yang menjawab soal dengan benar

JS = Jumlah seluruh peserta tes

Dalam Penelitan ini tingkat kesukaran suatu analisis butir soal dihitung dengan bantuan program microsoft excel. Berikut Tabel 3.3 klasifikasi tingkat kesukaran menurut (Arikunto, 2013). yaitu:

Tabel 3.3 Klasifikasi Tingkat Kesukaran Butir Soal

\section{Tingkat Nilai $P$}

Kesukaran

\begin{tabular}{ll}
\hline Terlalu sukar & TK $=0,00$ \\
Sukar & $0,00<T K \leq 0,30$ \\
Sedang & $0,30<T K \leq 0,70$ \\
Mudah & $0,70<T K<1,00$ \\
Terlalu mudah & TK $=1,00$ \\
\hline
\end{tabular}

Dalam Penelitian ini tingkat kesukaran akan diukur dengan program microsoft excel.

4. Daya Pembeda

Menurut (Sundayana, 2014) Rumus untuk mencari Daya Pembeda sebagai berikut: 


$$
D=\frac{B_{A}}{J_{A}}-\frac{B_{B}}{J_{B}}=P_{A}-P_{B}
$$

Keterangan :

$\mathrm{D}=$ Daya pembeda

$J_{A}=$ Banyaknya peserta kelompok atas.

$J_{B}=$ Banyaknya peserta kelompok bawah .

$B_{A}=$ Banyaknya peserta kelompok atas yang menjawab dengan benar

$B_{B}=$ Banyaknya peserta kelompok bawah yang menjawab benar.

$P_{A}=$ Proporsi peserta kelompok atas yang menjawab benar

$P_{B}=$ Proporsi kelompok bawah yang menjawab benar

Berikut klasifikasi Tingkat Daya Pembeda menurut (Arikunto, 2013) dapat dilihat pada Tabel 3.4 sebagai berikut :

\begin{tabular}{cc} 
Tabel 3.4 Klasifikasi Tingkat & Daya Pembeda So \\
\hline Tingkat Daya Pembeda & Interpretasi \\
\hline Sangat jelek & $\mathrm{DP}=0,00$ \\
Jelek & $0,00<D P \leq$ \\
& 0,20 \\
Cukup & $0,20<D P \leq$ \\
Baik & 0,40 \\
& $0,40<D P \leq$ \\
Sangat Baik & 0,70 \\
& $0,70<D P \leq$ \\
\hline
\end{tabular}

Dalam Penelitian ini tingkat daya beda akan diukur dengan program microsoft excel

5. Efektivitas pengecoh

Pengecoh berjalan dengan baik jika dapat menggiring peserta tes untuk memilih atau sekurang-kurangnya telah dipilih oleh peserta minimal $5 \%$ dari keseluruhan peserta tes. Teknik yang dilakukan melalui penghitungan proposisi dengan rumus sebagai berikut.

$$
\mathrm{IP}=\frac{\mathrm{P}}{(\mathrm{N}-\mathrm{B}) /(\mathrm{n}-1)} \times 100 \%
$$

\footnotetext{
Keterangan :

IP : Indeks Pengecoh

$\mathrm{P}$ : Jumlah peserta didik yang memilih pengecoh

$\mathrm{N}$ : Jumlah peserta didik yang ikut tes

B : Jumlah peserta didik yang menjawab benar pada soal

$\mathrm{n}$ : Jumlah alternatif jawaban (opsi)

1 : Bilangan tetap

Jika jumlah peserta didik menjawab benar pada butir soal tertentu (sesuai kunci jawaban ), maka IP = 0 yang berarti soal tersebut jelek . dengan demikian pengecoh tidak berfungsi (Sundayana, 2014).
} 
Dalam menyimpulkan efektivitas pengecoh pada setiap butir soal, peneliti menggunakan kriteria yang diadaptasi dari Skala Likert sebagai berikut:

Tabel 3.5 Kriteria Penilaian Efektivitas Pengecoh

\begin{tabular}{cc}
\hline $\begin{array}{c}\text { Banyak pengecoh } \\
\text { yang berfungsi }\end{array}$ & Kriteria \\
\hline 3 & Sangat Baik \\
2 & Baik \\
1 & Cukup Baik \\
0 & Tidak Baik \\
\hline
\end{tabular}

Penjelasan dari tabel kriteria penilaian efektivitas pengecoh di atas sebagai berikut.

a. Apabila ketiga jawaban pengecoh soal dapat berfungsi dengan baik, maka soal dapat dikatakan memiliki efektivitas pengecoh yang sangat baik.

b. Apabila terdapat dua jawaban pengecoh yang berfungsi maka soal dikatakan memiliki efektivitas pengecoh yang baik.

c. Apabila terdapat satu jawaban pengecoh yang berfungsi maka soal dikatakan memiliki efektivitas pengecoh yang cukup baik.

d. Apabila semua jawaban pengecoh tidak berfungsi maka soal dikatakan memiliki efektivitas pengecoh yang tidak baik.

\section{HASIL PENELITIAN}

Hasil yang diperoleh dari analisis Soal Ulangan Semester Ganjil Mata Pelajaran Matematika Kelas VIII SMP yang ditinjau dari beberapa aspek berikut:

\section{Validitas}

Pengujian validitas yang digunakan menggunakan rumus korelasi point biserial $\left(\gamma_{p b i}\right)$ dengan bantuan program Microsoft Excel. Hasil perhitungan validitas tersebut selanjutnya di konsultasikan $r_{\text {tabel }}$ pada taraf signifikansi $5 \%$ dengan jumlah peserta tes yang mengikuti Ulangan Semester Ganjil Mata Pelajaran Matematika Kelas VIII SMP Negeri 1 Kediri Pada Tahun Ajaran 2018/2019 adalah sebanyak 46 siswa. Pada taraf 5\% diperoleh nilai $r_{\text {tabel }}$ sebesar 0,291 sehingga apabila $r_{p b i} \geq r_{\text {tabel }}$ maka butir soal tersebut dinyatakan valid. Sebaliknya jika $r_{p b i}<r_{\text {tabel }}$ maka butir soal dinyatakan tidak valid. Berdasarkan hasil analisis Soal Ulangan Semester Ganjil Mata Pelajaran Matematika Kelas VIII SMP Negeri 1 Kediri Pada Tahun Ajaran 2018/2019. Terdapat 14 soal atau sebesar $70 \%$ dinyatakan valid dan 6 soal atau $30 \%$ dinyatakan tidak valid berikut penjabaran butir soal berdasarkan pengujian validitas.

Tabel 4.1 Hasil Analisis Butir Soal Ulangan Semester Ganjil Mata Pelajaran Matematika Kelas VIII SMP Negeri 1 Kediri Pada Tahun Ajaran 2018/2019 Berdasarkan Indeks Viditas.

\begin{tabular}{lllcc}
\hline No & Validitas & \multicolumn{1}{c}{ No Butir Soal } & Jumlah & $\begin{array}{c}\text { Persentas } \\
\text { e }\end{array}$ \\
\hline 1 & $\begin{array}{l}\geq 0,291 \\
\text { (valid) }\end{array}$ & $\begin{array}{l}1,2,4,9,11,12,13,14, \\
15,16,17,18,19,20,\end{array}$ & 14 & $70 \%$ \\
& & &
\end{tabular}


Jumlah

Sumber : Data diolah

2. Reliabilitas

Pengujian reliabilitas pada soal Ulangan Semester Ganjil Mata Pelajaran Matematika Kelas VIII SMP dilakukan secara manual dengan bantuan program Microsoft Excel dan menggunakan rumus KR-20. Hasil dari perhitungan tersebut, kemudian diinterprestasikan dengan kriteria jika $r_{11} \geq 0,70$ maka soal dapat dikatakan memiliki reliabilitas yang tinggi.

Berdasarkan perhitungan secara manual diketahui soal tersebut memiliki reliabilitas sebesar 0,80, sehingga dapat disimpulkan bahwa soal Ulangan Semester Ganjil Mata Pelajaran Matematika Kelas VIII SMP memiliki tingkat reliabilitas tinggi atau reliable karena nilai $r_{11}>0,70$.

3. Daya Pembeda

Daya pembeda soal adalah kemampuan suatu butir soal untuk membedakan siswa yang berkemampuan tinggi dengan siswa yang berkemampuan rendah. Soal yang baik adalah soal yang mampu membedakan jawaban siswa yang berkemampuan tinggi dengan siswa yang berkemampuan rendah. Dimana sebuah soal dinyatakan mempunyai daya pembeda yang baik jika jawaban siswa berkemampuan tinggi akan lebih banyak menjawab soal dengan benar dibandingkan dengan siswa yang berkemampuan rendah.

Kemampuan sebuah butir soal dalam membedakan jawaban siswa yang berkemampuan tinggi dengan siswa yang berkemampuan rendah dapat di lihat dari besar indeks daya pembeda untuk menentukan besarnya indeks daya pembeda siswa menjadi dua kelompok atas yaitu kelompok siswa yang berkemampuan tinggi dan kelompok bawah dengan siswa yang berkemampuan rendah dimana cara untuk menentukan kelompok atas dan kelompok bawah misalnya dengan dibagi dua 50\% kelompok atas dan 50\% kelompok bawah.

Sehingga didapatkan perhitungan daya pembeda menggunakan bantuan Program Microosft Excel. Dengan jumlah subjek dalam penelitian ini adalah 46 siswa. Cara menghitung daya pembeda dengan mengurangkan hasil siswa yang menjawab benar pada kelompok atas dengan hasil siswa yang menjawab benar pada kelompok bawah dibagi siswa kelompok bawah. Berikut hasil perhitungan daya pembeda yang didapatkan:

Tabel 4.2 Rekapitulasi Soal Ulangan Semester Ganjil Mata Pelajaran Matematika Kelas VIII SMP Berdasarkan Indeks Daya Beda

\begin{tabular}{cllcc}
\hline Nilai Diskriminasi & $\begin{array}{l}\text { Kategor } \\
\text { i }\end{array}$ & Butir Soal & $\begin{array}{l}\text { Jumla } \\
\text { h }\end{array}$ & $\begin{array}{l}\text { Persentas } \\
\text { e }\end{array}$ \\
\hline $\mathrm{DP}=0,00$ & $\begin{array}{l}\text { Sangat } \\
\text { jelek }\end{array}$ & 6 & 1 & $5 \%$ \\
& & & \\
$0,00<D P \leq 0,20$ & Jelek & 8 & 1 & $5 \%$ \\
$0,20<D P \leq 0,40$ & Cukup & $\begin{array}{l}3,5,7,9,10, \\
12,17,19,20\end{array}$ & 9 & $45 \%$ \\
$0,40<D P \leq 0,70$ & Baik & $\begin{array}{l}4,11,13,15, \\
16,20\end{array}$ & 6 & $30 \%$ \\
& & & &
\end{tabular}




\begin{tabular}{|c|c|c|c|c|}
\hline $0,70<D P \leq 1,00$ & $\begin{array}{l}\text { Sangat } \\
\text { tinggi }\end{array}$ & $1,2,18$ & 3 & $15 \%$ \\
\hline & umlah & & 20 & \\
\hline
\end{tabular}

4. Tingkat Kesukaran

Perhitunga indeks tingkat kesukaran dilakukan dengan microsoft excel. Hasil perhitungan tingkat kesukaran diinterpetasikan kedalam lima kategori yaitu : soal dengan TK 0,00 adalah soal tergolong terlalu sukar; soal dengan TK 0,00 sampai dengan 0,30 adalah soal tergolong sukar; soal dengan TK 0,30 sampai dengan 0,07 adalah soal tergolong sedang; soal dengan TK 0,70 sampai dengan 1,00 adalah soal tergolong mudah: soal dengan TK 1,00 adalah soal tergolong terlalu mudah. Berdasarkan hasil perhitungan terdapat 2 butir soal atau $10 \%$ yang termasuk kedalam soal yang sukar, 17 butir soal atau $85 \%$ termasuk kedalam soal yang sedang, dan 1 butir soal atau $5 \%$ yang termasuk kedalam saol yang mudah. Berikut penjabaran berdasarkan indeks tingkat kesukaran.

Tabel 4.3 Rekapitulasi Soal Ulangan Semester Ganjil Mata Pelajaran Matematika Kelas Viii SMP Berdasarkan Tingkat Kesukaran

\begin{tabular}{|c|c|c|c|c|}
\hline Kategori & Nilai $\mathbf{P}$ & Nomor soal & Jumlah & Persentase \\
\hline Sukar & $\begin{array}{l}0,00<T K \leq \\
0,30\end{array}$ & 7,8 & 2 & $10 \%$ \\
\hline Sedang & $\begin{array}{l}0,30<T K \leq \\
0,70\end{array}$ & $\begin{array}{l}1,2,3,4,5,6,10,11,12, \\
1314,15,16,17,18,19,20\end{array}$ & 17 & $85 \%$ \\
\hline Mudah & $\begin{array}{l}0,70<T K \leq \\
1,00\end{array}$ & 9 & 1 & $5 \%$ \\
\hline \multicolumn{3}{|c|}{ Jumlah } & 20 & $100 \%$ \\
\hline
\end{tabular}

Sumber : Data diolah

5. Efektivitas Pengecoh

Efektivitas Pengecoh atau distraktor dapat diketahui dengan melihat pola sebaran jawaban para siswa. Pengecoh yang baik ditandai dengan dipilih oleh sedikitnya 5\% dari peserta tes. Jadi apabila suatu alternatif pilihan jawaban yang salah memiliki indeks pengecoh lebih dari 5\% maka alternatif jawaban tersebut berfungsi dengan baik.

a. Apabila ketiga jawaban pengecoh soal dapat berfungsi dengan baik, maka soal dapat dikatakan memiliki efektivitas pengecoh yang sangat baik.

b. Apabila terdapat dua jawaban pengecoh yang berfungsi maka soal dikatakan memiliki efektivitas pengecoh yang baik.

c. Apabila terdapat satu jawaban pengecoh yang berfungsi maka soal dikatakan memiliki efektivitas pengecoh yang cukup baik.

d. Apabila semua jawaban pengecoh tidak berfungsi maka soal dikatakan memiliki efektivitas pengecoh yang tidak baik.

Berdasarkan hasil analisis terdapat 15 butir soal atau $75 \%$ memiliki efektivitas pengecoh yang sangat baik, 5 butir soal atau $25 \%$ memiliki efektivitas pengecoh yang baik. Berikut berdasarkan hasil analisis butir soal ulangan yang dilakukan didapatkan hasil sebagai berikut: 
Tabel 4.5 Rekapitulasi Soal Ulangan Semester Ganjil Mata Pelajaran Matematika Kelas VIII SMP Berdasarkan Efektivitas Pengecoh

\begin{tabular}{ccccc}
\hline No & $\begin{array}{c}\text { Kriteria } \\
\text { Kualitas Soal }\end{array}$ & No Butir & umlah & $\begin{array}{c}\text { Persenta } \\
\text { se }\end{array}$ \\
\hline 1 & Sangat Baik & $1,2,4,5,7,10,11,12,13,14$, & 15 & $75 \%$ \\
& & $15,17,18,19,20$ & & \\
2 & Baik & $3,6,8,9,16$ & 5 & $25 \%$ \\
3 & Kurang Baik & - & - & $0 \%$ \\
4 & Tidak Baik & - & - & $0 \%$ \\
& & Jumlah & 20 & $100 \%$ \\
\hline
\end{tabular}

Sumber: Data diolah

\section{PEMBAHASAAN}

Penelitian ini dilakukan dengan tujuan untuk mengetahui kualitas butir Soal Ulangan Semester Ganjil Mata Pelajaran Matematika Kelas VIII SMP. Setelah dilakukan analisis butir soal dengan menggunakan program Microsoft Excel diperoleh hasil kualitas butir soal yang meliputi validitas, reliabilitas, tingkat kesukaran, daya beda, dan efektivitas pengecoh.

\subsection{Validitas Item}

Validitas item bertujuan untuk mengetahui apakah suatu tes sudah tepat digunakan sebagai alat ukur. (Sudijono, 2015). validitas Item dari suatu tes adalah ketepatan mengukur yang harus dimiliki oleh sebutir Item (yang merupakan bagian tak terpisahkan dari tes sebagai suatu totalitas), dalam mengukur apa yang seharusnya diukur lewat butir Item tersebut. Tes hasil belajar dapat berbentuk pemberian tugas atau serangkaian pertanyaan-pertanyaan yang harus dikerjakan oleh peserta didik. Nilai yang diperoleh dapat melambangkan tingkah laku atau prestasi hasil belajar peserta didik.

Suatu tes dapat dikatakan memiliki validitas yang baik apabila suatu tes itu dapat mengukur apa yang seharusnya diukur dan sesuai dengan indeks korelasi point biserial. Jika tes yang digunakan guru kurang baik, maka hasil yang diperoleh pun tentunya kurang baik. Hal ini dapat merugikan siswa itu sendiri. Artinya, hasil yang diperoleh siswa menjadi tidak objektif dan tidak adil. Oleh sebab itu, tes yang digunakan guru harus memiliki kualitas yang lebih baik. Selain tes yang digunakan baik laporan hasil penelitian yang dilaporkan oleh peneliti juga harus sesuai dengan data yang sebenarnya terjadi. Hal ini sesuai dengan yang dinaytakann (Muluki, 2020). valid adalah data yang tidak berbeda antar data yang dilaporkan oleh peneliti dengan data yang sesungguhnya terjadi pada obyek penelitian.

Dalam penelitian ini peneliti menggunakan perhitungan dengan bantuan program Microsoft Excel. Hasil dari perhitungan tersebut kemudian dikonsultasikan dengan $\mathrm{r}$ tabel pada taraf signifikansi $5 \%$. Jumlah subyek penelitian adalah 46 siswa dan jumlah soal sebanyak 20 butir, sehingga pada taraf signifikansi $5 \%$ diperoleh nilai $r_{\text {tabel }}$ sebesar 0,291. Apabila hasil analisis menunnjukkan $r_{p b i} \geq 0,291$ maka butir soal tersebut dinyatakan valid, sebaliknya jika $r_{p b i}<0,291$ maka soal tersebut dinyatakan tidak valid. 
Berdasarkan hasil analisis butir Soal Ulangan Semester Ganjil Mata Pelajaran Matematika Kelas VIII SMP terdapat 14 soal atau $70 \%$ dinyatakan valid yakni butir soal $1,2,4,9,11,12,13,14,15,16,17,18,19$, dan 20 . Sedangkan 6 soal atau 30\% dinyatakan tidak valid yakni butir soal nomor $3,5,6,7,8$ dan 10 .

Menurut (Arifin, 2017). Suatu instrumen dikatakan valid apabila mampu mengukur apa yang diinginkan. Soal yang valid (70\%) berarti butir soal tersebut sudah dapat menjalankan fungsinya yaitu mengukur apa yang dapat diukur. Sedangkan soal yang tidak valid (30\%) dapat disebabkan dari beberapa faktor. Menurut pendapat yang dinyatakan Grounlund dalam (Arifin, 2017) ada tiga faktor yang mempengaruhi validitas hasil tes yaitu faktor instrumen yang digunakan untuk tes, faktor administrasi dan penskoran, serta faktor dari jawaban siswa.

Pada soal ulangan semester ganjil mata pelajaran matematika kelas VIII SMP dapat dipengaruhi dari kecenderungan siswa yang menjawab secara cepat namun tidak tepat. Cara agar mengurangi angka tidak valid yang disebabkan faktor jawaban dari siswa adalah dengan mengurangi kecendenrungan siswa menjawab secara cepat namun tidak tepat. Hal itu dapat dilakukan dengan sedikit menambah waktu untuk mengerjakan soal agar siswa punya waktu untuk mengecek kembali jawabannya dan tidak terburu- buru dalam menjawab soal.

Berdasarkan Uraian diatas dapat disimpulkan bahwa soal ulangan semester ganjil mata pelajaran Matematika Kelas VIII SMP memiliki kualitas yang baik dari segi validitasnya yang tinggi.

\subsection{Reliabilitas}

Reliabilitas instrumen penelitian adalah suatu alat yang memberikan hasil tetap sama (konsisten). Hasil pengukuran itu harus tetap sama (relatif sama) jika pengukurannya diberikan diberikan pada subjek yang sama meskipun dilakukan oleh orang yang berbeda pula, waktu yang berlainan, dan tempat yang berbeda pula (Sundayana, 2014) Suatu tes dikatakan memiliki tingkat reliabilitas yang baik apabila tes mampu memberikan hasil yang tetap walaupun diuji ke subjek yang berbeda atau diwaktu yang berbeda. Sedangkan menurut (Noni, 2015). tes dikatakan reliable jika memberikan hasil yang tepat apabila diteskan berkali-kali. Susunan tes dikatakan objektif apabila dalam melaksanakan tes itu tidak ada faktor subjektif yang mempengaruhi. Kemudian sebuah tes dikatakan memiiliki praktisibilitas tinggi apabila tes tersebut bersifat praktis, yaitu mudah dilaksanakan, mudah pemeriksaannya, dan dilengkapi dengan petunjuk- petunjuk yang jelas.

Perhitungan reliabilitas pada Soal Ulangan Semester Ganjil Mata Pelajaran Matematika Kelas VIII SMP dilakukan secara manual dengan bantuan program Microsoft Excel. Jumlah butir soal sebanyak 20 soal. Reliabilitas soal dalam penelitian ini dihitung dengan menggunakan rumus KR-20. Apabila $r_{11} \geq 0,70$ berarti tes hasil belajar yang diuji reliabilitasnya dinyatakan telah memilik reliabilitas yang tinggi (reliable). Sedangkan apabila $r_{11}<0,70$ berarti tes hasil belajar yang diuji dinyatakan belum memiliki tingkat reliabilitas yang tinggi (rendah atau tidak reliable). Menurut Gronlund dalam (Arifin, Z. 2017). ada empat faktor yang dapat mempengaruhi reliabilitas, yaitu panjang tes, sebaran skor, tingkat kesukaran dan objektivitas.

Hasil penelitian ini menunjukkan bahwa soal Ulangan Semester Ganjil Mata Pelajaran Matematika Kelas VIII SMP memiliki indeks reliabilitas 0,80. Berdasarkan hasil tersebut maka dapat dikatakan bahwa Soal Ulangan Semester Ganjil Mata Pelajaran Matematika Kelas VIII SMP termasuk kategori reliable karena nilai $r_{11} \geq 0,70$. Kondisi derajat reliabilitas yang tinggi ini cukup sesuai dengan validitas yang tinggi. 
Sesuai dengan pendapat (Arikunto, 2013). bahwa sebuah tes mungkin reliable tetapi tidak valid. Sebaliknya, sebuah tes yang valid biasanya reliable. Maksudnya tes yang valid sudah pasti reliabel sebaliknya tes yang reliabel belum tentu valid.

Berdasarkan uraian diatas maka dapat disimpulkan bahwa nilai reliabilitas Soal Ulangan Semester Ganjil Mata Pelajaran Matematika Kelas VIII SMP masih termasuk dalam kategori soal yang baik dilihat dari segi reliabilitasnya yang tinggi.

\subsection{Tingkat Kesukaran}

Tingkat kesukaran adalah keberadaan suatu butir soal apakah dipandang sukar, sedang, atau mudah dalam mengerjakannya (Sundayana, 2014). Bermutu atau tidaknya butir-butir item tes hasil belajar pertama- tama dapat diketahui dari derajat kesukaran atau taraf kesulitan yang dimiliki oleh masing-masing butir item tersebut. Butir-butir item tes hasil belajar dapat dinyatakan sebagai butir-butir item yang baik, apabila butir-butir item tersebut tidak terlalu sukar dan tidak pula terlalu mudah dengan kata lain derajat kesukaran item itu adalah sedang atau cukup.

Hasil penelitian ini menunjukkan bahwa butir Soal Ulangan Semester Ganjil Mata Pelajaran Matematika Kelas VIII SMP berdasarkan hasil perhitungan terdapat 17 butir soal atau $85 \%$ dikatakan memiliki tingkat kesukaran sedang yakni item nomor 1 , $2,3,4,5,6,10,11,12,13,14,15,16,17,18,19$ dan 20. Kemudian 1 butir soal atau 5\% dikatakan berkategori mudah yakni item nomer 9. Dan 2 buir soal atau $10 \%$ berkategori sukar yakni item nomer 7 dan 8 .

Hasil penelitian menunjukkan bahwa soal Ulangan Semester Ganjil Mata Pelajaran Matematika Kelas VIII SMP yang memiliki tingkat kesukaran sedang, karena jumlah soal yang berkategori sedang berjumlah $85 \%$ dan soal yang berkategori sukar berjumlah $10 \%$ dan yang berkategori mudah 5\%. Sedangkan menurut (Waminton, 2015) untuk menyusun suatu naskah ujian sebaiknya digunakan butir soal yang memiliki tingkat kesukaran berimbang, yaitu: soal berkategori sukar sebanyak 25\%, kategori sedang 50\% dan kategori mudah 25\%. Hal tersebut menyebabkan soal memiliki kualitas kurang baik dari segi tingkat kesukaran. Menurut (Arifin, 2017). penghitungan tingkat kesukaran soal adalah pengukuran seberapa besar derajat kesukaran suatu soal. Jika suatu soal memiliki tingkat kesukaran seimbang (proporsional), maka dapat dikatakan bahwa soal tersebut baik. Hasil penelitian ini sesuai dengan teori tujuan tes. Tes yang digunakan untuk keperluan ujian semester memang seharusnya menggunakan soal dengan tingkat kesukaran sedang. Sementara itu, soal yang digunakan untuk keperluan seleksi menggunakan soal dengan tingkat kesukaran tinggi dan soal yang biasanya untuk keperluan diagnose menggunakan soal dengan tingkat kesukaran rendah atau mudah. Jadi, soal ujian akhir semester memang sebaiknya menggunakan soal dengan tingkat kesukaran sedang.

Berdasarkan uraian di atas dapat diambil kesimpulan bahwa Soal Ulangan Semester Ganjil Mata Pelajaran Matematika Kelas VIII SMP berdasarkan tingkat kesukarannya masuk dalam kriteria kurang baik. Soal yang masuk dalam kriteria mudah sebaiknya dilakukan perbaikan dengan mengganti kalimat agar lebih panjang dan kompleks sehingga untuk mengerjakannya siswa harus berpikir lebih dalam

\subsection{Daya Pembeda}

Perhitungan daya pembeda pada Soal Ulangan Semester Ganjil Mata Pelajaran Matematika Kelas VIII SMP Negeri 1 Kediri Pada Tahun Ajaran 2018/2019 menggunakan bantuan program Microsof Excel. Hasil perhitungan daya pembeda di interprestasikan menjadi tiga kriteria yaitu: soal $\mathrm{DP}=0,00$ adalah soal sangat jelek ; soal dengan DP 0,00 sampai 0,20 adalah soal yang tergolong jelek ; soal dengan DP 
0,20 sampai 0,40 adalah soal yang cukup; soal dengan DP 0,40 sampai dengan 0,70 adalah soal yang baik dan saol dengan DP 0,70 sampai dengan 1,00 adalah soal yang sangat tinggi.

Berdasarkan hasil analisis, terdapat 1 butir soal atau sebesar 5\% memiliki daya pembeda sangat jelek, 1 soal atau sebesar 5\% memiliki daya pembeda jelek, 9 butir soal atau sebesar $45 \%$ memiliki daya pembeda soal yang cukup, 6 soal atau 30\% memiliki daya pembeda baik dan 3 butir soal atau 15\% memiliki daya pembeda sangat tinggi.

Menurut (Waminton, R. 2015)daya pembeda soal adalah kemampuan suatu butir soal dapat membedakan antara siswa yang telah menguasai materi yang ditanyakan dan siwa yang belum menguasai materi yang ditanyakan. Didukung dengan (Sudijono, Anas. 2015) yang menyatakan bahwa dengan daya pembeda pada setiap butir soal sangat penting untuk diketahui karena salah satu pedoman dalam menyusun butir soal, penyusun soal harus menyadari bahwa kemampuan peserta didik berbeda-beda.

Berdasarkan pembahasan di atas dapat disimpulkan bahwa soal Ulangan Semester Ganjil Mata Pelajaran Matematika Kelas VIII SMP memiliki daya pembeda yang cukup. Karena 5\% soal memiliki daya pembeda sangat jelek, $5 \%$ soal memiliki daya pembedanya jelek, $45 \%$ memiliki daya pembeda soal yang cukup, $30 \%$ soal memiliki daya pembeda baik dan $15 \%$ memiliki daya pembeda sangat tinggi. Untuk butir soal dengan daya pembeda yang tidak baik sebaiknya tidak digunakan lagi untuk tes yang akan datang, karena butir soal tersebut kualitasnya sangat jelek. Kemudian butir soal yang sudah memiliki daya pembeda baik sebaiknya dimasukkan dalam bank soal tes hasil belajar, butir soal yang daya pembedanya yang cukup baik dapat diperbaiki dan di revisi.

\subsection{Efektivitas Pengecoh}

Efektivitas Pengecoh diperoleh dengan menghitung banyaknya siswa yang memilih jawaban a, b, c dan d atau tidak memilih jawaban apapun. Pengecoh dikatakan baik apabila jumlah peserta tes yang memilih pengecoh itu sama atau mendekati jumlah ideal. Pengecoh dapat dikatakan berfungsi dengan baik apabila paling sedikit dipilih oleh 5\% dari jumlah peserta tes (Sudijono, 2015). Hasil analisis Efektivitas Pengecoh Soal Ulangan Semester Ganjil Mata Pelajaran Matematika Kelas VIII SMP menunjukkan sebanyak 15 butir atau $75 \%$ memiliki pengecoh yang sangat baik, 5 butir soal atau $25 \%$ memiliki pengecoh yang baik, 0 memiliki pengecoh yang kurang baik $0 \%$, dan 0 memiliki pengecoh yang tidak baik. Menurut (Sudijono, 2015) tindak lanjut atas hasil penganalisisan terhadap fungsi distraktor tersebut adalah yang sudah dapat menjalankan fungsinya dengan baik dapat dipakai lagi pada tes-tes yang akan datang, sedangkan distraktor yang belum dapat berfungsi dengan baik sebaiknya diperbaiki atau diganti dengan yang lain.

Dengan demikian dapat disimpulkan bahwa soal ulangan semester ganjil mata pelajaran matematika kelas VIII SMP berdasarkan efektivitas pengecoh termasuk soal baik dari segi pengecohnya, karena jumlah soal yang memiliki efektivitas yang kurang baik $0 \%$ dari soal.

\section{KESIMPULAN}

Berdasarkan analisis butir soal dari segi Validitas, Reliabilitas, Daya Pembeda, Tingkat Kesukaran dan Efektivitas Pengecoh pada soal Ulangan Semester Ganjil Mata Pelajaran Matematika Kelas VIII SMP, diperoleh kesimpulan sebagai berikut.

a. Validitas Soal Ulangan Semester Ganjil Mata Pelajaran Matematika Kelas VIII SMP tergolong soal yang valid karena $r_{p b i} \geq r_{\text {tabel }}$. 
b. Reliabilitas Soal Ulangan Semester Ganjil Mata Pelajaran Matematika Kelas VIII SMP Negeri 1 Kediri Pada Tahun Ajaran 2018/2019 tergolong soal yang memiliki Reliabilitas tinggi karena $r_{11}>0,70$.

c. Daya Pembeda Soal Ulangan Semester Ganjil Mata Pelajaran Matematika Kelas VIII SMP tergolong soal memiliki Daya Pembeda yang cukup, karena 9 butir soal atau $45 \%$ memiliki daya pembeda yang cukup.

d. Tingkat Kesukaran Soal Ulangan Semester Ganjil Mata Pelajaran Matematika Kelas VIII tergolong soal yang memiliki Tingkat Kesukaran sedang karena 17 butir soal atau $85 \%$ memiliki tingkat kesukaran sedang.

e. Efektivitas Pengecoh Soal Ulangan Semester Ganjil Mata Pelajaran Matematika Kelas VIII SMP didominasi oleh soal yang memiliki Efektivitas Pengecoh yang sangat baik karena 15 butir soal atau $75 \%$ memiliki pengecoh yang sangat baik.

\section{REFERENSI}

Arifin, Z. 2017. Evaluasi Pembelajaran. Bandung: PT. Remaja Rosdakarya.

Arikunto, Suharsimi. 2013. Dasar-Dasar Evaluasi Pendidikan. Edisi 2. Jakarta: Bumi Aksara.

Hamzah, Ali. 2014. Evaluasi Pembelajaran Matematika. Jakarta: Rajawali Pers.

Jufri, A. W. 2013. Belajar dan Pembeljaran Sains. Bandung : Pustaka Reka Cipta.

Muluki, A., Bundu. P., \& Sukmawati. (2020). Analisis Kualitas Butir Tes Semester Ganjil Mata Pelajaran IPA Kelas IV Mi Radhiatul Adawiyah. Jurnal Ilmiah Sekolah Dasar, 4(1), 86-96.

Nitko, A. J. 1996 . Educational Assessments studenets. Prentice Hall PT. New York.

Noni, N., \& Marlianingsih. (2015). Analisis Butir Soal Pilihan Ganda dari Aspek Kebahasaan. Faktor Jurnal Ilmu Pendidikan. 2(1), 69:77.

Sudijono, Anas. 2015. Pengantar Evaluasi Pendidikan. Jakarta: PT. Raja Grafindo Persada.

Sundayana, Rostina. 2014. Statistika Penelitian Pendidikan. Bandung: Alfabeta.

Waminton, R. 2015. Evaluasi Hasil Belajar Matematika. Yogyakarta: Media Akademi. 